\title{
Veronika Lukas, Wilfried Stroh, Claudia Wiener
}

Christus und Cupido. Embleme aus Jacob Baldes Poetenklasse von 1628.

Jesuitica: Quellen und Studien zu Geschichte, Kunst und Literatur der

Gesellschaft Jesu im deutschsprachigen Raum, Band 18. Regensburg: Schnell und

Steiner, 2013. Pp. 251. Hb, 39.95 EUR.

The genre of love emblems flourished for two hundred years, beginning with the publication of Andrea Alciato's Emblematum liber in 1531. Religious interpretations used the popular Cupid motif to contrast the effects of worldly love with those of divine love. One charming example is Otto van Veen's emblem "Conscientia testis" ("Conscience is a witness," in his Amoris divini emblemata, 1615): there, Worldly Love, poised at the start of the smooth road to Babylon, embraces the globe, while Divine Love, the globe beneath its feet, points to the steep road leading to Jerusalem. In the foreground the human (feminine) soul is taking a blood test with Cupid's arrow in order to determine which way her conscience advises her to choose. Van Veen's collection marked the beginning of the religious type of love emblem, which was elaborated by many Jesuits, among them the German poet and satirist Jacob Balde, whose early emblem book De Dei et mundi amore was produced together with his pupils in Munich in 1628. Balde's sixty-five emblems are not usually included in emblem bibliographies; this first modern edition is thus very welcome.

The volume includes three introductory essays: Günter Hess and Wilfried Stroh describe the emblem tradition and its love motif; Claudia Wiener focuses on manuscript transmission and the use of emblems in Jesuit schools. The edition of the emblems includes transcriptions of the original Latin epigrams, their German translations, and short commentaries on each image. Like other Jesuits, Balde emphasized the spiritual and moral messages of the love emblem. But unlike van Veen or Herman Hugo, a Jesuit who produced the most popular religious emblem book of the time, Pia desideria, just two years before Balde's work, Balde did not focus on divine love and its virtuous effects. Instead, his interest was in worldly love and its harm, and it is this peculiar satirical approach that distinguishes Balde's emblems from the wider tradition. Balde's profane Cupid is associated with death, skeletons, graveyards, and stinking corpses, thereby stressing the harmful effects of human love. For a Balde scholar, these emblems are rewarding because, as Hess and Stroh aptly point out, the images show how the basic contrast between sacred and worldly values, which was thematically so important to Balde's entire oeuvre, was already shaping his early thinking. Balde's early poetic work, De vanitate mundi (1638), insightfully contributed to the vanitas motif by describing how all empires and all of men's great deeds, including those preserved on "eternal monuments," 
are gradually destroyed. Balde's later work, Urania victrix (1663), contrasted the Christian soul with the five senses, personified as human beings. Both of these works playfully denounced worldly pleasures and praised more permanent values.

The emblems also help us to understand the strongly visual nature of Balde's poetry and demonstrate Balde's characteristic originality, visible, for example, in the way he uses the image of the globe: sometimes the little love god plays on the globe's two halves as if they were kettledrums; sometimes the globe forms a huge trumpet through which Cupid blows and creates earthly music. At times the globe is carried by hunchbacks, parodies of Atlas holding the sky on his shoulders. Often the images involve a choice of directions between divine love and worldly love. The cover image (the emblem on fol. 26) is well chosen: earthly materiality is depicted as an enormous elephant, which fails to fly up to heaven despite help from the birds. One minor shortcoming of the volume is that while giving a general picture of the love motif, the introductory essays start with the Roman love elegy, but without emphasizing that the Cupid motif also enjoyed wide popularity in early modern British and Italian literature and art. Yet overall, the present volume is a useful contribution to the little studied Neo-Latin emblems and to Balde scholarship in particular by making his largely unknown early work available to modern readers.

\author{
Sari Kivistö \\ University of Helsinki \\ sari.kivisto@helsinki.fi
}

